\title{
The communities of ectomycorrhizal fungal species associated with Betula pendula RoTH and Pinus sylvestris L. growing in heavy-metal contaminated soils
}

\author{
Wojciech Bierza (1D) Karolina Bierza • Artur Trzebny • \\ Izabela Greń • Miroslawa Dabert • Ryszard Ciepal • \\ Lidia K. Trocha
}

Received: 15 March 2020 /Accepted: 7 October 2020 /Published online: 19 October 2020

(C) The Author(s) 2020

\begin{abstract}
Aims Pioneer tree species such as Betula pendula and Pinus sylvestris encroach soils contaminated with heavy metals (HMs). This is facilitated by ectomycorrhizal fungi colonizing tree roots. Thus, we evaluated the ectomycorrhizal fungal (EMF) communities of $B$. pendula and $P$. sylvestris growing in HMcontaminated soils compared to non-contaminated soils. We also studied the effect of HMs and soil properties on EMF communities and soil fungal biomass.

Methods Roots of B. pendula and P. sylvestris were collected from three HM-contaminated sites and from two non-contaminated sites located in Poland. EMF
\end{abstract}

Responsible Editor: Erik J. Joner.

Electronic supplementary material The online version of this article (https://doi.org/10.1007/s11104-020-04737-4) contains supplementary material, which is available to authorized users.

W. Bierza $(\bowtie) \cdot$ K. Bierza $\cdot$ I. Greń $\cdot$ R. Ciepał Faculty of Natural Sciences, Institute of Biology, Biotechnology and Environmental Protection, University of Silesia in Katowice, Jagiellońska 28, 40-032 Katowice, Poland

e-mail: wojciech.bierza@us.edu.pl

A. Trzebny $\cdot$ M. Dabert

Faculty of Biology, Molecular Biology Techniques Laboratory, Adam Mickiewicz University, Uniwersytetu Poznańskiego 6, 61-614 Poznań, Poland

L. K. Trocha

Faculty of Biology, Department of Plant Ecology and Nature Protection, Adam Mickiewicz University, Uniwersytetu Poznańskiego 6, 61-614 Poznań, Poland species were identified using DNA barcoding. Soil fungal biomass was determined by soil ergosterol.

Results B. pendula and P. sylvestris growing in HMcontaminated soils had similar EMF communities, where Scleroderma, Rhizopogon and Russula as well as ectomycorrhizae of the long-distance exploration type dominated. Among all of the examined soil factors studied, toxicity index $\left(\mathrm{TI}_{\text {Total }}\right)$ was the most significant factor shaping the composition of EMF communities. Despite significant differences in the structure of the EMF communities of trees growing in HMcontaminated sites compared to control sites, no differences in overall diversity were observed.

Conclusions Only well-adapted EMF species can survive toxic conditions and form ectomycorrhizal symbiosis with encroaching trees facilitating the forest succession on contaminated soils.

Keywords Ectomycorrhiza $\cdot$ Next generation sequencing (NGS) · Heavy metal pollution · Pioneer tree species $\cdot$ Silver birch $\cdot$ Scots pine
Abbreviations
ROS Reactive Oxygen Species
HM Heavy Metal
GSH Glutathione
MTs Metallothioneins
EMF Ectomycorrhizal Fungi
ECM Ectomycorhiza
OTU Operational Taxonomic Unit
HPLC High-Performance Liquid Chromatography
DAD Diode-Array Detector 
TI Toxicity Index

NMDS Non-metric Multidimensional Scaling

CCA Canonical Correspondence Analysis

\section{Introduction}

The southern part of Poland has been a centre of the lead and zinc industry since the Middle Ages (Grodzińska et al. 2000). This region has been ranked as one of the most polluted regions in Europe (Piekut et al. 2019). Several smelters, associated industrial plants, and ore mines are still in use resulting in the accumulation of high levels of toxic heavy metals (HMs) in soils, particularly in the upper soil layers (Augustyniak et al. 2014), where the highest density of fine root (Jackson et al. 1996) and ectomycorrhizal root tips (Rosling et al. 2003) occurs.

The uptake and accumulation of heavy metals in plant tissues causes various adverse morphological, physiological and biochemical responses (Doğanlar and Atmaca 2011). HMs induce the production of reactive oxygen species (ROS) which hinder cell metabolism and have multiple toxic effects, including lipid peroxidation and damage to proteins and DNA (Pongrac et al. 2009). HMs also block and displace essential functional groups in biomolecules (Schützendübel and Polle 2002). As a consequence, HMs can inhibit photosynthesis and diminish water and nutrient uptake, resulting in chlorosis, growth inhibition, browning of root tips, and eventual plant death (Seregin and Ivanov 2001).

Several pioneer tree species occur naturally or are intentionally introduced in HMs polluted areas. The most common trees in polluted soils in Eastern Europe are silver birch (Betula pendula Roth.) (Prach and Pyšek 2001) and Scots pine (Pinus sylvestris L.) (PiconCochard et al. 2006). Long-lived organisms such as trees can overcome high (i.e. toxic) concentrations of HMs in soils through resistance (sensu Levitt 1980) mechanisms including ectomycorrhizal symbiosis (Wilkinson and Dickinson 1995). Jourand et al. (2010) and Gonçalves et al. (2009) postulated that HM-resistant EMF ecotypes strongly enhance the growth of host plants on nickelcontaminated areas. Elevated concentrations of HMs in ectomycorrhizal root tips indicate that the fungal mantle is an effective barrier that prevents transport of these elements to roots of higher branch order, shoots, and leaves (Leyval et al. 1997; Turnau et al. 2002). For example, Blaudez et al. (2000) stated that binding Cd in the cell walls of fungal hyphae and HM accumulation in the vacuolar compartment of fungal cells should be considered as two essential HM-detoxification mechanisms in ectomycorrhizal fungi (EMF). Courbot et al. (2004) reported an increase in glutathione (GSH) concentration in Paxillus involutus mycelia growing under Cd-stress conditions as glutathione can form highly stable complexes with $\mathrm{Cd}$ and other thiophilic HMs such as $\mathrm{Hg}, \mathrm{Cu}$, and Zn (Rubino 2015). Additionally, metallothioneins (MTs), cysteine-rich heavy metal-binding peptides, have also been found in EMF tissues (Courbot et al. 2004; Ramesh et al. 2009). Moreover, ectomycorrhizal fungi can secrete several compounds into the soil that can immobilize HMs outside the mycelium (AhonenJonnarth et al. 2000). Although EMFs possess many mechanisms responsible for HM resistance, Pennanen et al. (1996) observed a reduction in the fungal biomass in HM-contaminated soils.

Several studies have investigated the EMF communities occurring in HM-contaminated sites (Huang et al. 2012; Krpata et al. 2008; López-García et al. 2018; Regvar et al. 2010) so far. However, none of these studies has compared the EMF species communities and associated fungal biomass between two naturally growing tree species. Therefore, this study characterized and compared the EMF communities of Betula pendula (silver birch) and Pinus sylvestris (Scots pine) growing around zinc-lead smelters and compared them with noncontaminated (control) sites. Additionally, the effects of HMs and associated soil properties on EMF communities and soil fungal biomass were also investigated.

We hypothesized that EMF communities associated with $B$. pendula and $P$. sylvestris growing in HMcontaminated soils should be more similar to each other than EMF communities associated with the same tree species growing in non-contaminated areas. The expected similarity of EMF communities of silver birch and Scots pine growing in HM-contaminated sites would be due to an increased contribution of specific, probably HM-resistant, EMF species.

\section{Material and methods}

Study sites

The study was carried out in three HM-contaminated sites located in the close vicinity of large non-ferrous 
metal smelters in southern Poland (Fig. 1): Szopienice $\left(50^{\circ} 15^{\prime} 46^{\prime \prime} \mathrm{N}, 19^{\circ} 04^{\prime} 23^{\prime \prime} \mathrm{E} ; 256 \mathrm{~m}\right.$ asl), Miasteczko Ślaskie (50 30' $12^{\prime \prime} \mathrm{N}, 18^{\circ} 56^{\prime} 08^{\prime \prime} \mathrm{E}$; $301 \mathrm{~m}$ asl), and Bukowno (50 $10^{\circ} 22^{\prime \prime} \mathrm{N}, 19^{\circ} 28^{\prime} 31^{\prime \prime} \mathrm{E} ; 346 \mathrm{~m}$ asl). The area around the Szopienice smelter has been exposed to HM pollution for over 170 years (Augustyniak et al. 2014). Miasteczko Ślaskie and Bukowno sites have been under constant and increasing heavy metal pollution since 1967 when both smelters were established (Azarbad et al. 2015). The control sites (noncontaminated with heavy metals) were located in Kórnik (52 $14^{\prime} 22^{\prime \prime} \mathrm{N}, 17^{\circ} 04^{\prime} 46^{\prime \prime} \mathrm{E}$; $85 \mathrm{~m}$ asl), central Poland, and in Złoty Potok (Parkowe Reserve) (50 $42^{\prime} 14{ }^{\prime} \mathrm{N}$, $19^{\circ} 25^{\prime} 24^{\prime \prime} \mathrm{E} ; 316 \mathrm{~m}$ asl), southern Poland. We chose these control sites according to their well-known management history and their use in other similar studies (e.g. Łukasik 2006: Rudawska et al. 2011).

Three plots of $B$. pendula and three of $P$. sylvestris, ranging in age from 25 to 35 years old, were established in the Bukowno and Miasteczko Śląskie sites. Two plots of $B$. pendula and two of $P$. sylvestris, ranging in age from 20 to 25 years old were established at the Szopienice site. Similarly, two plots of B. pendula and two plots of $P$. sylvestris ranging between 20 and 35 years old were established at each of the control sites, Kórnik and Złoty Potok. Each of the established plots was approximately $100 \mathrm{~m}^{2}$ and was located from 10 to $300 \mathrm{~m}$ from each other. The soils of Miasteczko Śląskie, Kórnik and Złoty Potok are characterised as Podzols (Jaśniska-M'Bodj 2015; Misiorny 2009; Wierzbicki 2012), while soils from Bukowno and Szopienice are described as Technosols (Górniak 2010; Szeremeta 2010).

Sample collection and processing

Five soil samples (approximately $500 \mathrm{~g}$ each) were collected randomly in September 2015 and 2016 from each plot at the study sites for a total of 120 samples. Soil samples were collected from a depth of 0-15 cm after removing litter, stored in closed plastic bags, and refrigerated for no longer than $24 \mathrm{~h}$ until processed. Two subsamples $(100 \mathrm{~g})$ were taken from each of the collected samples, homogenized (mixed and sieved to $<2 \mathrm{~mm}$ ), and either air-dried for chemical analysis or stored at $-20{ }^{\circ} \mathrm{C}$ for fungal biomass assessment.

Simultaneously, other soil samples $(20 \mathrm{~cm}$ long $\times$ $20 \mathrm{~cm}$ wide $\times 15 \mathrm{~cm}$ deep) were collected and stored in sealed plastic bags and placed at $-20{ }^{\circ} \mathrm{C}$ for ectomycorrhizal evaluation. Roots in thawed samples were gently extracted from the soil with tweezers and washed under tap water over a $1 \mathrm{~mm}$ sieve. Tightly adhering materials were removed manually with forceps under a stereomicroscope (Olympus, zoom 0.67-40). The number of healthy-looking ectomycorrhizal root tips of B. pendula and P. sylvestris were recorded separately. Exploration types of ectomycorrhizae were classified based on Agerer (2001). Ectomycorrhizae of Russula, Lactarius, and Hygrophorus, of which their species-specific information was unavailable, were grouped together and described as a separate category (contact/short/medium-smooth, c $/ \mathrm{s} / \mathrm{m}_{\mathrm{s}}$ ).

Approximately $50 \mathrm{~g}$ of fresh $B$. pendula leaves and $P$. sylvestris needles were collected from five randomly selected trees three times during the growing season in 2015 and 2016. Leaves and needles were used to assess the degree of plant HM-contamination in each site.

\section{Chemical analyses}

Soil $\mathrm{pH}$ was measured using a $1: 2.5$ soil to $1 \mathrm{M} \mathrm{KCl}$ solution ratio. Organic matter content expressed as carbon (C) content was measured using the loss of ignition method. Total nitrogen $(\mathrm{N})$ content was determined by the Kjeldahl method. The content of available phosphorus $(\mathrm{P})$ was measured using the Egner-Riehm method. The total concentrations of $\mathrm{HMs}(\mathrm{Cd}, \mathrm{Pb}, \mathrm{Zn}, \mathrm{Cu}, \mathrm{Ni})$ and $\mathrm{Ca}$ were analyzed according to the methodology proposed by Sastre et al. (2002) and was obtained by mineralization of $0.25 \mathrm{~g}$ of soil in $8 \mathrm{ml}$ of concentrated $\mathrm{HNO}_{3}$ and $2 \mathrm{ml}$ of $30 \% \mathrm{H}_{2} \mathrm{O}_{2}$ in a microwave oven (Milestone Ethos One, Italy) at $190{ }^{\circ} \mathrm{C}$. After mineralization, samples were diluted to $25 \mathrm{ml}$ with deionized water and filtered. The fraction of available HMs was obtained by shaking a soil sample $(1: 10$ soil to solution ratio) with $0.01 \mathrm{M} \mathrm{CaCl}_{2}$ for $2 \mathrm{~h}$ (Wójcik et al. 2014). The content of HMs was measured using flame absorption spectrometry (Thermo Scientific iCE 3500, USA). All of the analyses included blank samples (distilled water) and certified reference materials (NCS DC 77302, China National Analysis Centre for Iron and Steel) to ensure the quality of the analyses.

Leaves and needles were rinsed three times with distilled water, dried at $105{ }^{\circ} \mathrm{C}$, and homogenized in an agate mill (Retsch, Germany). Powder samples were then divided into three $0.25 \mathrm{~g}$ subsamples and each were mineralized in $8 \mathrm{ml}$ of $65 \% \mathrm{HNO}_{3}$ and $2 \mathrm{ml}$ of $30 \%$ $\mathrm{H}_{2} \mathrm{O}_{2}$ in a microwave oven (Milestone Ethos One, Italy) 
Fig. 1 General geographical map describing the location of the study sites

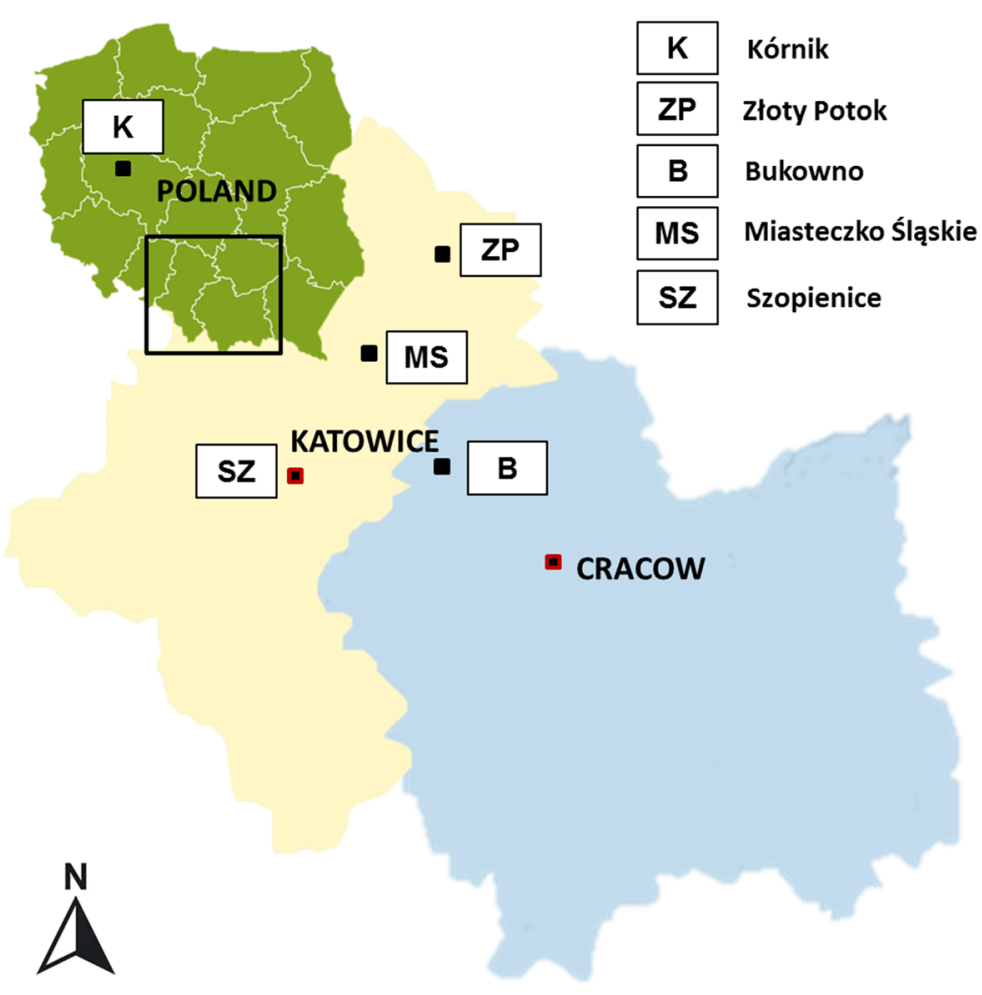

at $190{ }^{\circ} \mathrm{C}$. After mineralization, samples were diluted to $25 \mathrm{ml}$ with deionized water and filtered. The HM content in each sample was determined using flame absorption spectrometry (Thermo Scientific iCE 3500, USA). Only $\mathrm{Cd}, \mathrm{Pb}, \mathrm{Zn}$, and $\mathrm{Cu}$ were determined in plant material. Ni was not included because its concentration in leaves and needles was below the detection limit. All of the analysis procedures included blank samples (distilled water) and certified reference material (Oriental Basma Tobacco Leaves [INCT-OBTL-5], Institute of Nuclear Chemistry and Technology, Poland) to ensure the quality of the analyses.

\section{DNA extraction and next generation sequencing}

A total of 15,800 root tips collected from B. pendula and 9744 from $P$. sylvestris were analyzed (Table S1). Before molecular analysis, ECM root tips were pooled by plot and analyzed separately. Ectomycorrhizal root tips collected from each plot were placed in $2 \mathrm{ml}$ tubes containing Lysing Matrix A (MP Biomedicals, USA). After the addition of $450 \mu \mathrm{l}$ of ATL lysis buffer (Qiagen, Germany), samples were homogenized three times for $40 \mathrm{~s}$ at a speed of $6.5 \mathrm{~m} \mathrm{~s}^{-1}$ using a FastPrep-24 homogenizer (MP Biomedicals). Proteinase K (Bio Basic,
Canada) was added to the solution to a final concentration of $0.2 \mathrm{mg} \mathrm{ml}^{-1}$ and samples were then incubated for $24-48 \mathrm{~h}$ at $56{ }^{\circ} \mathrm{C}$. Subsequently, $100 \mu \mathrm{l}$ of the lysate from each sample was used to isolate total genomic DNA using the ZR-69 Quick-gDNA MiniPrep Kit (Zymo Research).

The Internal transcribed spacer 1 (ITS1) was PCRamplified using ITS1 (TCCGTAGGTGAACC TGCGG) and ITS2 (GCTGCGTTCTTCATCGATGC) primers (White et al. 1990) and fused with Ion Torrent double indexed adapters. PCRs were prepared in two technical replicates, each in a reaction volume of $5 \mu 1$ containing Type-it Microsatellite Kit (Qiagen), 2.5 $\mu \mathrm{M}$ of each primer, and $1 \mu \mathrm{l}$ of DNA template. The amplification program was as follows: $95{ }^{\circ} \mathrm{C}$ for $5 \mathrm{~min}$, followed by 35 cycles of $30 \mathrm{~s}$ at $95{ }^{\circ} \mathrm{C}, 60 \mathrm{~s}$ at $50{ }^{\circ} \mathrm{C}$ and $30 \mathrm{~s}$ at $72{ }^{\circ} \mathrm{C}$ with a final extension step at $72{ }^{\circ} \mathrm{C}$ for $7 \mathrm{~min}$.

Technical replicates were merged and diluted with $10 \mu \mathrm{l}$ of deionized water. $5 \mu \mathrm{l}$ of the diluted PCR mixture was electrophoresed on a $1.5 \%$ agarose gel to check amplification efficiency. Then, all amplicons were pooled in equimolar amounts, size-selected on a $3 \%$ agarose gel and purified using QIAquick Gel Extraction Kit (Qiagen) according to the manufacturer's 
protocol. DNA concentration and fragment length distribution of the library was established with the use of a High Sensitivity D1000 Screen Tape assay on 2200 Tape Station system (Life Technologies, USA). Clonal template amplification was performed using the Ion Torrent One Touch System II and the Ion PGM Hi-Q View OT2 Kit (Life Technologies, USA) according to the manufacturer's instructions. The library was sequenced using an Ion PGM Hi-Q View Sequencing Kit, Ion 318 chip and the Ion PGM system (Life Technologies).

\section{Bioinformatics analysis}

Sequence reads $<200 \mathrm{bp}$ were removed from the dataset in Geneious R11.1.5 (Biomatters Ltd.). Then, the Fastx toolkit (Hannon 2010) was used to extract sequences having a minimum of $50 \%$ of bases with a quality score $\geq 25$. In Geneious R11.1.5, quality filtered sequences were separated into individual combinations of indices representing each site. Chimeras were removed using two approaches: the default settings in UCHIME version 4.2.40 (Edgar 2016), and the SILVA database for ARB for small subunit ribosomal RNAs version 132 (Glöckner et al. 2017) as implemented in Geneious R11.1.5 (Biomatters Ltd.). Operational taxonomic unit (OTU) clustering was performed at $97 \%$ similarity in USEARCH version 11.0.667 (Edgar 2010). Singletons ( $<5$ reads) were removed, and OTUs were then clustered using the -cluster_OTUs algorithm (Edgar 2013). Fungal OTU consensus sequences were compared to the Unite (Kõljalg et al. 2013) and MycoBank (Robert et al. 2013) databases to identify EMF species using a 97\% identity threshold (Table S2).

Fungal biomass in soils

Ergosterol concentration was used as an indicator of total living fungal (saprophytic and mycorrhizal) biomass in soils (Olsson et al. 1996). This indicator accounts also for both Ascomycetes and Basidiomycetes (Olsson et al. 2003). Analysis was performed according to the method previously described by Gong et al. (2001) with a few modifications proposed by de Ridder-Duine et al. (2006). One gram of soil and $6 \mathrm{ml}$ of methanol was added to a $20 \mathrm{ml}$ scintillation vial containing $2 \mathrm{~g}$ of acid-washed glass beads (1 $\mathrm{g}$ of $500 \mu \mathrm{m}$ diameter and $1 \mathrm{~g}$ of $1000 \mu \mathrm{m}$ diameter) and then intensively shaken for $1 \mathrm{~h}$. Subsequently, a $1.5 \mathrm{ml}$ aliquot from each sample was transferred into a plastic tube and centrifuged for $15 \mathrm{~min}$ at $14000 \mathrm{rpm}$. Ergosterol concentration was measured by HPLC (MerckHitachi, Germany) with a LiChrospher® RP-18 HPLC Column $(4 \times 250 \mathrm{~mm})$ using pure methanol (HPLC grade) as a mobile phase at a flow rate of $1 \mathrm{ml} \mathrm{min}^{-1}$. The DAD detection (Merck-Hitachi, Germany) was set at $282 \mathrm{~nm}$. As a standard $\geq 95.0 \%$ Ergosterol HPLC grade (Sigma-Aldrich) was used.

\section{Statistics}

The level of HM contamination was characterized using the toxicity indices for both total $\left(\mathrm{TI}_{\mathrm{Total}}\right)$ and available $\left(\mathrm{TI}_{\mathrm{Bio}}\right.$ ) concentrations of heavy metals (Stefanowicz et al. 2008):

$\mathrm{TI}=\sum_{i}^{n}\left(C_{i} / \mathrm{EC} 0_{i}\right)$

where $C_{i}$ is the concentration of heavy metal $i$ in soil and $E_{C 50}$ is the concentration of that heavy metal causing a $50 \%$ reduction in dehydrogenase activity $\left(\mathrm{EC} 50_{\mathrm{Cd}}=90\right.$, $\mathrm{EC} 50_{\mathrm{Cu}}=35, \mathrm{EC} 50_{\mathrm{Ni}}=100, \mathrm{EC} 50_{\mathrm{Pb}}=652, \mathrm{EC} 50_{\mathrm{Zn}}=$ $115 \mathrm{mg} \mathrm{kg}^{-1}$ ) according to Welp (1999), where EC (effective concentration) values were estimated with the Levenberg-Marquardt algorithm and a Weibull distribution of data to calculate nonlinear regressions. Experiment was performed with soil material from the plough layer $(0-30 \mathrm{~cm})$ of a loess soil (FAO: haplic luvisol), passed through a 2-mm sieve.

Rarefaction curves were generated using PAST ver. 3.25 (Hammer et al. 2001) in order to evaluate the representativeness of our sampling effort. Diversity of EMF communities was expressed using taxa richness, Shannon's, dominance $\left(\mathrm{D}=\Sigma\left(\mathrm{p}_{i}\right)^{2}\right.$, where $\mathrm{p}_{i}$ is the relative number of sequences of taxon $i$ ), evenness and Margalef diversity, indices were determined using PAST ver. 3.25 (Hammer et al. 2001). Taxonomic diversity and taxonomic distinctness was analyzed according to Warwick and Clarke (1998), using taxonomic division, class, order and family as group information. The relative abundance (\%) of EMF species were calculated based on the number of sequence reads of each particular EMF species out of all sequence reads at each plot, or site, expressed as $100 \%$. These calculations were done separately for silver birch and Scots pine.

The normality of distribution of analyzed data was studied using the Kolomogorov-Smirnov test. 
Homogeneity of variance between the studied groups (contaminated vs. non-contaminated sites; $B$. pendula vs. $P$. sylvestris) was analyzed with the Levene test. In the case of a lack of normal distribution of raw data, the Box-Cox transformation was performed. Differences in soil chemical parameters, the EMF diversity indices, and soil ergosterol concentration between both tree species and contaminated vs. non-contaminated sites were analyzed using a one-way ANOVA followed by a Tukey's post-hoc test at $\alpha=0.05$. To verify the effect of locality a two way nested ANOVA test was performed with factors "tree", "contamination" plus the factor "locality" nested in the factor "tree". The above statistical analyses were performed using Statistica v. 13.0 (Dell Inc.).

Differences among EMF communities were tested using permutational multivariate analysis of variance (PERMANOVA) with 999 permutations. Non-metric multidimensional scaling (NMDS) based on the BrayCurtis dissimilarity index was used to visualize the similarity between the EMF communities. The above multivariate analyses were carried out in PAST ver. 3.25 (Hammer et al. 2001).

Canonical Correspondence Analysis (CCA) was performed to study the relationships between the EMF species as well as exploration types and soil parameters (only variables with Variance Inflation Factor (VIF) > 20 were included). Scaling was based on inter-species distances using a biplot scaling type. The relative importance and statistical significance of each soil parameter in the ordination model was assessed by a forward selection procedure and the Monte Carlo permutation test ( $n=999$ permutations), and only significant parameters were used for the CCA. Analyzed data were standardized $(\log (n+1))$ prior to analysis. The multivariate analyses were performed using CANOCO ver. 4.5 (ter Braak and Šmilauer 2002).

\section{Results}

Soil and leaf/needle chemistry

The soils in the HM contaminated sites ranged from acidic (Miasteczko Śląskie) through neutral (Bukowno) to alkaline (Szopienice), while the soils in the control sites (Kórnik and Złoty Potok) were acidic (Table S3). Soils in the contaminated sites had both a total concentration of $\mathrm{HMs}$ and a toxicity index $\left(\mathrm{TI}_{\mathrm{Total}}\right)$ higher than soils in the control sites. Only soils in the Bukowno and Miasteczko Śląskie sites had significantly higher concentrations in both the bioavailable fraction of HMs and the $\mathrm{TI}_{\mathrm{Bio}}$ than those in the control sites. The concentrations of $\mathrm{Cd}, \mathrm{Pb}$, and $\mathrm{Zn}$ were 41 to 107,29 to 84 , and 38 to 173 times higher, respectively, in the contaminated sites then those in the control sites. The concentrations of $\mathrm{Cu}, \mathrm{Mn}$, and $\mathrm{Ni}$ were 7 to $28,0.4$ to 5 and 2 to 9 times higher, respectively, in the soils of contaminated sites compared to soils from the control sites. Most of the sites were macroelement-poor as evidenced by relatively low $\mathrm{C}, \mathrm{N}$ and $\mathrm{P}$ levels (Table S3). Differences between concentration of HMs in soils from plots of B. pendula and P. sylvestris were not statistically significant according to nested ANOVA (Table 1). However, there were differences in $\mathrm{Cu}_{\mathrm{Bio}}, \mathrm{C}$, $\mathrm{N}$, and $\mathrm{P}$ concentrations and soil $\mathrm{pH}$. Moreover, nested ANOVA indicated that the concentrations of HMs and other soil properties differed significantly between B. pendula and P. sylvestris within location.

A strong correlation, ranging from 0.5 to 0.8 , was observed between the concentration of heavy metal contaminations in soils and the concentration of heavy metals in leaves/needles (data not shown). Leaves of $B$. pendula and needles of $P$. sylvestris collected in the Miasteczko Śląskie site contained the highest concentration of HMs (Table S4). The lowest concentration of HMs was found in leaves and needles collected from trees in both control sites.

Ectomycorrhizal fungal communities

Analysis of the rarefaction curve showed that the read depth was sufficient to recover all EMF species in the tested sites (Fig. S1). A total of 65 EMF species were identified of which 64 were found in B. pendula and 54 in P. sylvestris (Table 2). In total, 25 EMF species were found in the contaminated soils, while 49 were identified in the non-contaminated (control) sites. A total of 53 EMF species were members of the Basidiomycota, while 12 were Ascomycota. The greatest number of identified species belonged to the family Russulaceae (17 species in total) with 13 species identified in the contaminated sites and 11 species in the control sites.

Scleroderma citrinum, Scleroderma sp.01, Rhizopogon sp.01, Russula decolorans, and Russula depallens were the most abundant among EMF communities associated with $B$. pendula in contaminated sites, while $R$. decolorans and Lactarius tabidus were 
Table 1 Results of two-way nested ANOVA; Tree - tree species (Betula pendula vs. Pinus sylvestris), Contamination - type of site (contaminated vs. non-contaminated), Tree (Locality) - effect of the site nested in tree species (within site effect)

\begin{tabular}{|c|c|c|c|c|c|c|}
\hline & \multicolumn{2}{|l|}{ Tree } & \multicolumn{2}{|c|}{ Contamination } & \multicolumn{2}{|c|}{ Tree (Locality) } \\
\hline & $\mathrm{F}$ & $p$ & $\mathrm{~F}$ & $p$ & $\mathrm{~F}$ & $p$ \\
\hline \multicolumn{7}{|l|}{ Total metals (mg kg ${ }^{-1}$ ) } \\
\hline $\mathrm{Cd}$ & 0.689 & 0.410 & 1642.078 & $0.000 *$ & 12.464 & $0.000 *$ \\
\hline $\mathrm{Pb}$ & 0.697 & 0.407 & 2006.752 & $0.000 *$ & 26.829 & $0.000 *$ \\
\hline $\mathrm{Zn}$ & 1.605 & 0.210 & 5030.055 & $0.000 *$ & 69.559 & $0.000 *$ \\
\hline $\mathrm{Cu}$ & 0.461 & 0.500 & 1040.092 & $0.000 *$ & 18.469 & $0.000 *$ \\
\hline $\mathrm{Mn}$ & 2.087 & 0.154 & 33.138 & $0.000 *$ & 70.121 & $0.000 *$ \\
\hline $\mathrm{Ni}$ & 3.965 & 0.051 & 742.764 & $0.000 *$ & 23.763 & $0.000 *$ \\
\hline $\mathrm{TI}_{\text {Total }}$ & 1.340 & 0.252 & 4510.340 & $0.000 *$ & 49.260 & $0.000 *$ \\
\hline \multicolumn{7}{|c|}{ Bioavailable metals $\left(\mathrm{mg} \mathrm{kg}^{-1}\right)$} \\
\hline $\mathrm{Cd}$ & 0.146 & 0.704 & 5135.326 & $0.000 *$ & 11.426 & $0.000 *$ \\
\hline $\mathrm{Pb}$ & 0.035 & 0.853 & 201.468 & $0.000 *$ & 36.349 & $0.000 *$ \\
\hline $\mathrm{Zn}$ & 3.739 & 0.058 & 5684.195 & $0.000 *$ & 30.084 & $0.000 *$ \\
\hline $\mathrm{Cu}$ & 7.681 & $0.007 *$ & 1.601 & 0.211 & 35.754 & $0.000 *$ \\
\hline $\mathrm{TI}_{\mathrm{Bio}}$ & 0.526 & 0.471 & 5702.127 & $0.000 *$ & 12.698 & $0.000 *$ \\
\hline $\mathrm{C}(\%)$ & 5.534 & $0.022 *$ & 22.550 & $0.000 *$ & 18.770 & $0.000 *$ \\
\hline $\mathrm{N}(\%)$ & 15.794 & $0.000 *$ & 5.901 & $0.018^{*}$ & 17.750 & $0.000 *$ \\
\hline $\mathrm{C} / \mathrm{N}$ & 4.575 & $0.037 *$ & 13.033 & $0.001 *$ & 48.367 & $0.000 *$ \\
\hline $\mathrm{P}\left(\mathrm{mg} \mathrm{P}_{2} \mathrm{O}_{5} \mathrm{~kg}^{-1}\right)$ & 52.021 & $0.000 *$ & 9.741 & $0.003 *$ & 48.141 & $0.000 *$ \\
\hline $\mathrm{Ca}\left(\mathrm{g} \mathrm{kg}^{-1}\right)$ & 18.354 & $0.000 *$ & 328.679 & $0.000 *$ & 96.678 & $0.000 *$ \\
\hline $\mathrm{pH}$ & 20.470 & $0.000^{*}$ & 916.590 & $0.000 *$ & 167.69 & $0.000 *$ \\
\hline Ergosterol $\left(\mu \mathrm{g} \mathrm{g}^{-1}\right)$ & 1.761 & 0.190 & 47.845 & $0.000 *$ & 6.005 & $0.000 *$ \\
\hline
\end{tabular}

Significant differences $(p \leq 0.05)$ are marked with *

dominant in $B$. pendula growing in the control sites (Table 2). Similarly, Rhizopogon sp.01 and S. citrinum dominated in P. sylvestris growing in the contaminated sites, while Suillus sp.01 and Russula vinosa dominated in $P$. sylvestris roots growing in the control sites.

A higher EMF richness was found in B. pendula and $P$. sylvestris growing in control sites than in the contaminated sites (Table 3). However, Shannon's diversity and dominance indices, did not differ significantly between contaminated and non-contaminated sites for either B. pendula $(\mathrm{F}=1.174, p=0.4$ and $\mathrm{F}=1.212, p=$ 0.385 respectively) and $P$. sylvestris $(\mathrm{F}=1.732, p=$ 0.247 and $\mathrm{F}=1.186, p=0.395$ respectively). Only the EMF community of $B$. pendula in the Bukowno site had a significantly higher evenness index $(\mathrm{F}=4.337, p=$ $0.04)$ and lower Margalef diversity index $(\mathrm{F}=10.437$, $p=0.004$ ). Moreover, we have found that taxonomic diversity and taxonomic distinctness did not differ significantly between contaminated and non-contaminated sites for either B. pendula $(\mathrm{F}=1.424, p=0.418$ and $\mathrm{F}=$ 1.82, $p=0.338$ respectively) and $P$. sylvestris $(\mathrm{F}=$ $0.741, p=0.593$ and $\mathrm{F}=0.862, p=0.531$ respectively) (Table 4).

The NMDS ordination clearly separated the EMF communities of contaminated from non-contaminated sites, irrespective of tree species (Fig. 2). More precisely, EMF communities of $B$. pendula $(\mathrm{F}=1.685, p=$ $0.024)$ and $P$. sylvestris $(\mathrm{F}=1.607, p=0.047)$ differed significantly between contaminated and noncontaminated sites based on the PERMANOVA test. The EMF communities also differed between $B$. pendula and $P$. sylvestris growing in the control sites ( $\mathrm{F}=1.584, p=0.031$ ), but no significant difference was observed between $B$. pendula and $P$. sylvestris growing in the contaminated sites $(\mathrm{F}=0.919, p=0.528)$.

The soil parameters $\left(\mathrm{TI}_{\mathrm{Total}}, \mathrm{TI}_{\mathrm{Bio}}, \mathrm{C} / \mathrm{N}\right.$ ratio, $\mathrm{Ca}$ and $\mathrm{P}$ content, $\mathrm{pH}$, and ergosterol concentration) used in the ordination (canonical correspondence analysis, CCA) 


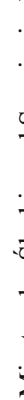

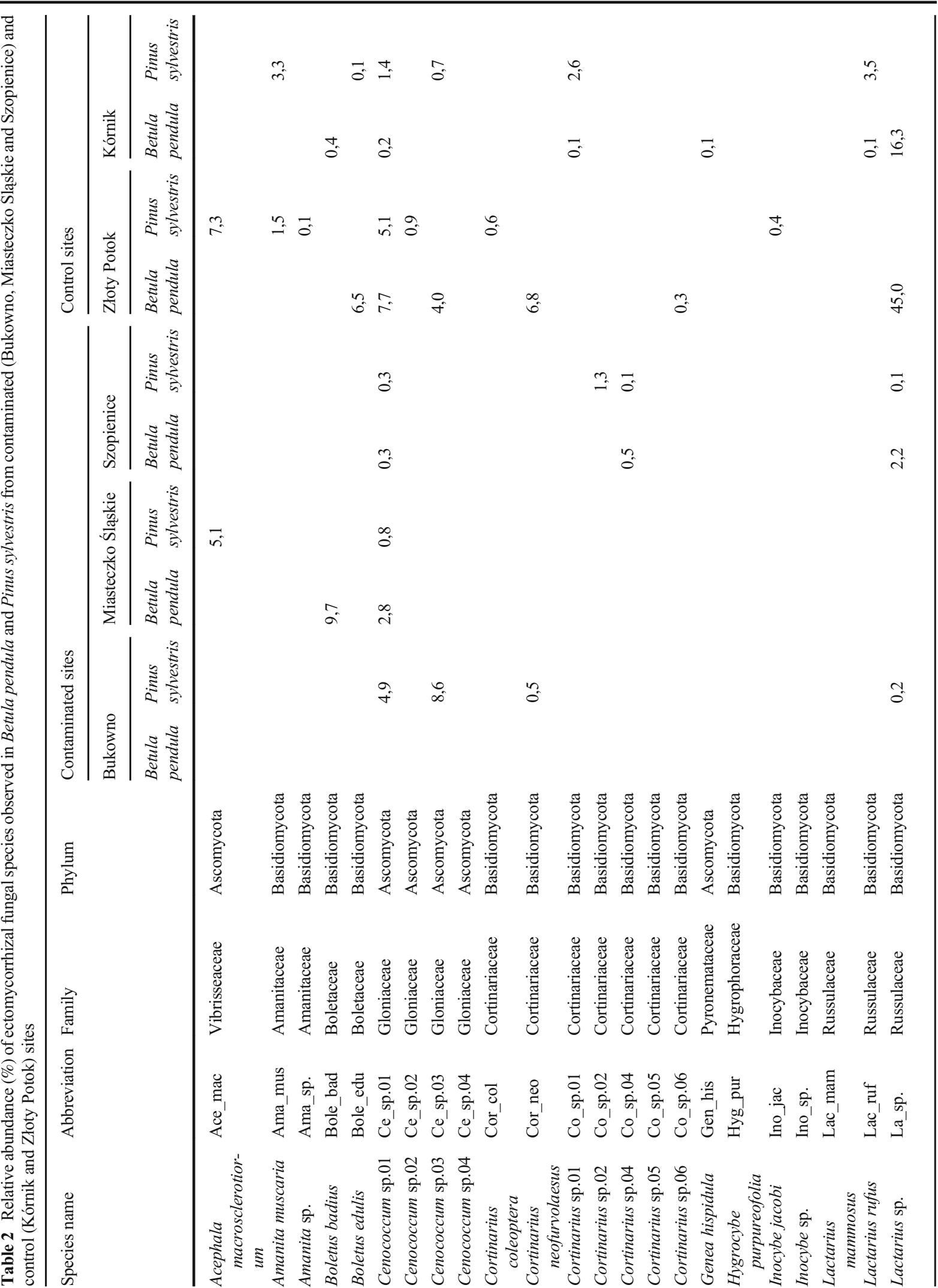




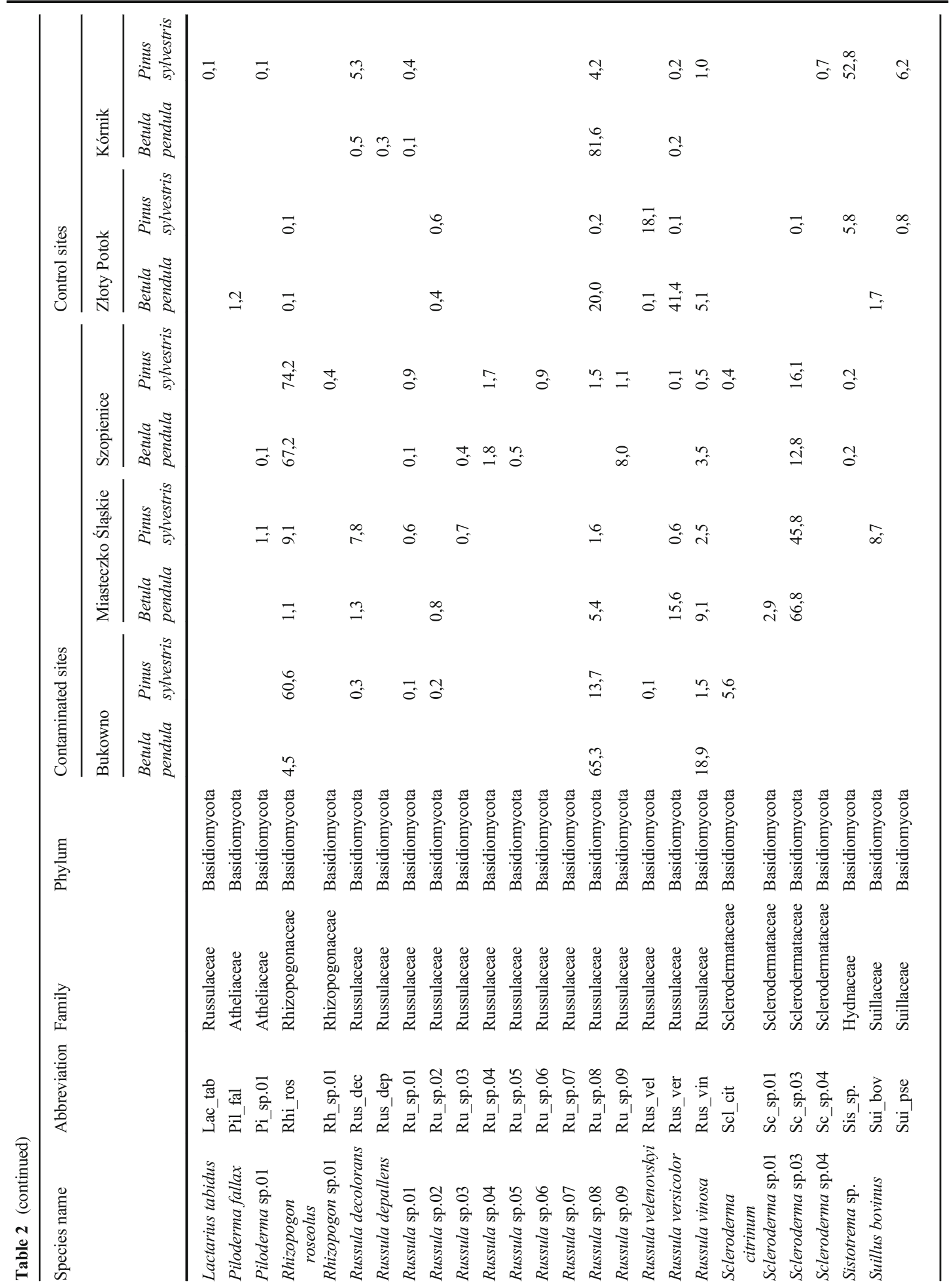




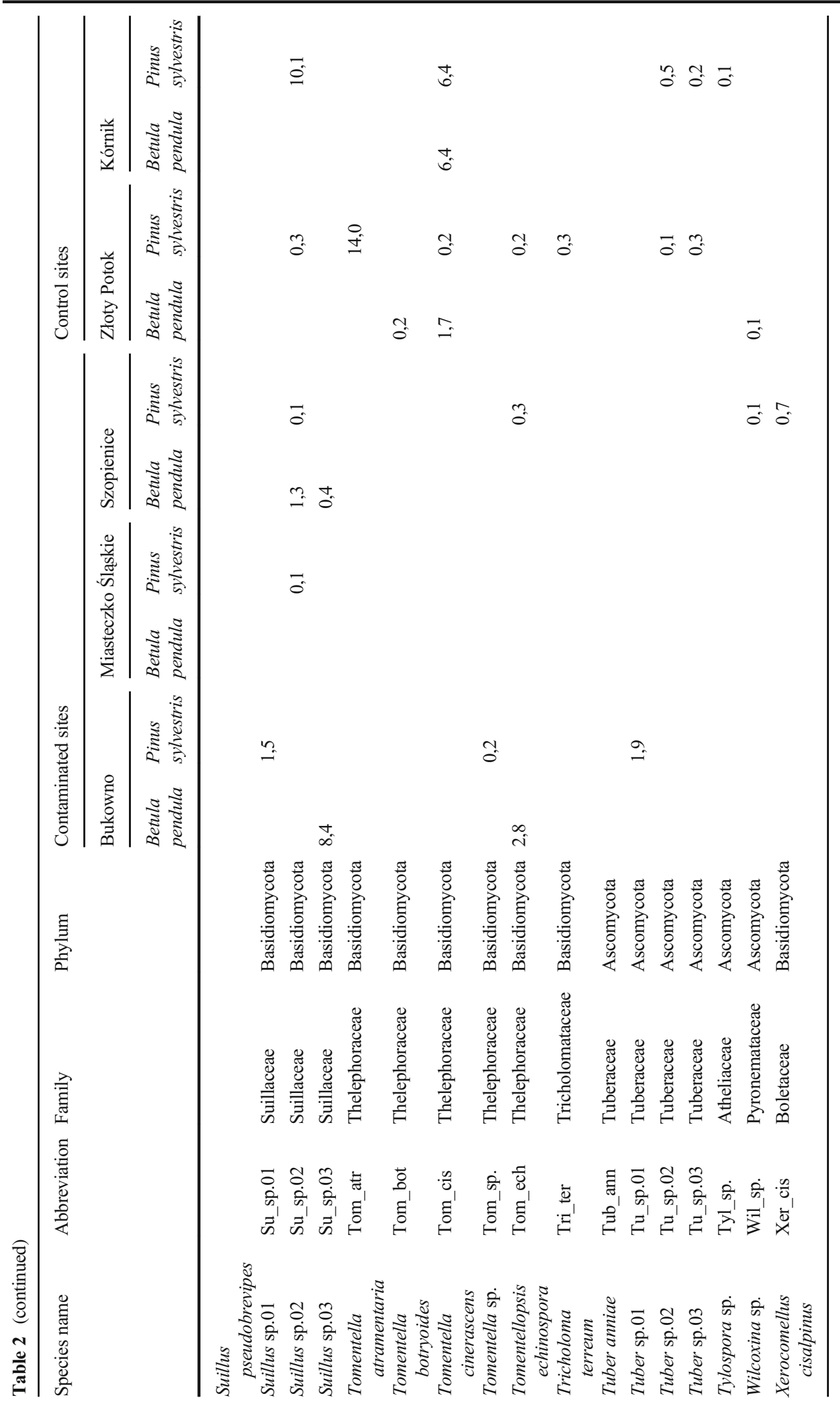


explained $77.25 \%$ of the total EMF variation (Fig. 3). The only significant factor was $\mathrm{TI}_{\text {Total, }}$ which explained $17.86 \%(\mathrm{~F}=1.76, p=0.001)$ of the variability. The CCA analysis further indicated that Scleroderma citrinum, Scleroderma sp.01, Rhizopogon sp.01, Rhizopogon roseolus, Russula sp.05, Russula sp.06, Russula sp.07, Russula sp.08, Cortinarius sp.06, were associated with high HM concentrations in the soil.

Exploration types of ectomycorrhizae

The composition of the ECM exploration types expressed as their relative abundance (\%) varied among sites (Fig. 4). Long-distance exploration type was the most abundant in the contaminated sites (from $70.9 \%$ to $92.2 \%$ ), except B. pendula in Bukowno where $\mathrm{c} / \mathrm{s} / \mathrm{m}_{\mathrm{s}}$ exploration type dominated (65.3\%). In the control sites, the most abundant were ectomycorrhizae of the $\mathrm{c} / \mathrm{s} / \mathrm{m}_{\mathrm{s}}$ type (from $70.0 \%$ to $99.1 \%$ ) except $P$. sylvestris in Kórnik where long-distance exploration type dominated (72.0\%). The first two axes of the CCA ordination based on soil parameters $\left(\mathrm{TI}_{\mathrm{Total}}, \mathrm{TI}_{\mathrm{Bio}}, \mathrm{C} / \mathrm{N}\right.$ ratio, $\mathrm{Ca}$ and $\mathrm{P}$ content, $\mathrm{pH}$, and ergosterol concentration) and ECM exploration types explained $93.66 \%$ of the species variance (Fig. 5). The only significant soil factors were $\mathrm{TI}_{\text {Total, }}$ which explained $54.81 \%(\mathrm{~F}=9.80, p=0.002)$ of the variability, and the $\mathrm{P}$ content, which explained $17.05 \%(\mathrm{~F}=4.18, p=0.020)$. The relative abundance of long-distance type was correlated with the $\mathrm{TI}_{\text {Total }}$, soil $\mathrm{pH}$ and $\mathrm{Ca}$ concentration.

\section{Soil fungal biomass}

CCA analysis (Fig. 3) indicated that the concentration of ergosterol was negatively correlated with $\mathrm{TI}_{\mathrm{Bio}}(\mathrm{R}=$ -0.73 ). However, no clear evidence was obtained, that indicated that the concentration of ergosterol was significantly lower in contaminated sites than in control sites (Fig. S2). Only in the case of B. pendula in Bukowno and $P$. sylvestris in Miasteczko Ślaskie was the concentration of ergosterol significantly lower than in the other sites $(\mathrm{F}=9.222, p<0.000$ and $\mathrm{F}=18.132$; $\mathrm{p}$ $<0.000$, respectively).

\section{Discussion}

To the best of our knowledge, this is the first study that has comprehensively examined the effect of heavy metals (as measured by toxicity index, TI) and associated soil properties on the composition of fungal communities associated with naturally established, pioneer $B$. pendula and $P$. sylvestris trees. Toxicity index was used because it most accurately reflects the combined effect of multiple HMs present in different proportions on soil microorganisms (Deng et al. 2015). In our study TI coefficients well reflected the influence of heavy metals on microorganisms. The results showed a statistically significant negative correlation between dehydrogenase activity and $\mathrm{TI}_{\text {Total }}(\mathrm{R}=-0.534, p<0.05)$ and $\mathrm{TI}_{\mathrm{Bio}}(\mathrm{R}=-0.478, \mathrm{p}<0.05)$ (data unpublished). This is also confirmed by Stefanowicz et al. (2008), Azarbad et al. (2015) in studies conducted on similar sites.

The availability of HMs to microorganisms and higher plant species depends to a large extent on the soil properties and in particular on soil $\mathrm{pH}$ (e.g. Baba et al. 2016). As the alkalinity of soil increases, the mobility and thus bioavailability of HMs decreases due to increased precipitation and displacement from the sorption complex by alkaline ions e. g. $\mathrm{Ca}$ and $\mathrm{Mg}$ (e.g. Ragnarsdottir and Hawkins 2006). For this reason, relatively high soil $\mathrm{pH}(7.5)$ at the $\mathrm{HM}$ contaminated Szopienice site resulted in $\mathrm{TI}_{\mathrm{Bio}}$ being comparable to that of the control sites. Nested ANOVA indicated that locality had a significant influence on differences of soil properties between $B$. pendula and $P$. sylvestris, which suggests that our results may be to some extent dependent on site selection.

The $\mathrm{TI}_{\text {Total }}$ coefficient was found to be the most important determinant shaping EMF communities. However, other factors, like soil $\mathrm{pH}$, may also have an influence on EMF communities. Trees growing at the contaminated sites have been constantly exposed to high concentrations of HMs for at least 20 years. Although an overall decline in EMF diversity was not observed (Table 3), significant differences in the structure of EMF communities between HM contaminated and control sites were found irrespective of the tree species, while such differences were evident when these tree species were growing in the control (noncontaminated) sites as shown by the PERMANOVA test. The similarity of EMF communities of $B$. pendula and $P$. sylvestris growing in the contaminated sites can be associated with the adaptation of some EMF species to high concentrations of HMs in soil (Colpaert et al. 2011). Other researchers postulate that sharing the same soil conditions also contributes significantly to the establishment of similar EMF species communities (Cline 
Table 3 Means ( \pm SE) of species richness, dominance, Shannondiversity, evenness and Margalef diversity indices of EMF communities associated with Betula pendula and Pinus sylvestris at contaminated (Bukowno, Miasteczko Śląskie, and Szopienice) and non-contaminated (Kórnik and Złoty Potok) sites; values within each column followed by the same letter are not significantly different according to Tukey's test at the $\alpha=0.05$ significance level

\begin{tabular}{|c|c|c|c|c|c|}
\hline Site & Species richness & Dominance & Shannon diversity & Evenness & Margalef diversity \\
\hline \multicolumn{6}{|l|}{ Betula pendula } \\
\hline Bukowno & 5 & $0.55(0.10) \mathrm{a}$ & $0.78(0.19) \mathrm{a}$ & $0.76(0.01) \mathrm{a}$ & $0.32(0.07) \mathrm{a}$ \\
\hline Miasteczko Śląskie & 9 & $0.47(0.03) \mathrm{a}$ & $1.06(0.06) \mathrm{a}$ & $0.55(0.10) b$ & $0.81(0.10) a b$ \\
\hline Szopienice & 17 & $0.23(0.02) \mathrm{a}$ & $1.73(0.07) \mathrm{a}$ & $0.49(0.11) b$ & $1.45(0.12) \mathrm{b}$ \\
\hline Kórnik & 17 & $0.63(0.36) \mathrm{a}$ & $0.85(0.78) \mathrm{a}$ & $0.25(0.14) b$ & $1.05(0.21) \mathrm{ab}$ \\
\hline Złoty Potok & 16 & $0.43(0.20) \mathrm{a}$ & $1.26(0.44) \mathrm{a}$ & $0.32(0.10) b$ & $1.39(0.30) \mathrm{b}$ \\
\hline \multicolumn{6}{|l|}{ Pinus sylvestris } \\
\hline Bukowno & 16 & $0.52(0.11) \mathrm{a}$ & $0.94(0.17) \mathrm{a}$ & $0.38(0.11) \mathrm{a}$ & $0.86(0.17) \mathrm{a}$ \\
\hline Miasteczko Śląskie & 14 & $0.58(0.16) \mathrm{a}$ & $0.83(0.31) \mathrm{a}$ & $0.57(0.13) \mathrm{a}$ & $0.61(0.29) \mathrm{a}$ \\
\hline Szopienice & 17 & $0.58(0.29) \mathrm{a}$ & $0.93(0.52) \mathrm{a}$ & $0.41(0.30) \mathrm{a}$ & $1.22(0.27) \mathrm{a}$ \\
\hline Kórnik & 20 & $0.35(0.16) \mathrm{a}$ & $1.51(0.39) \mathrm{a}$ & $0.39(0.17) \mathrm{a}$ & $1.55(0.01) \mathrm{a}$ \\
\hline Złoty Potok & 28 & $0.23(0.05) \mathrm{a}$ & $1.82(0.20) \mathrm{a}$ & $0.38(0.12) \mathrm{a}$ & $1.79(0.08) \mathrm{a}$ \\
\hline
\end{tabular}

et al. 2005; Trocha et al. 2012) as the soil is a strong filter for ECM fungi as proposed by Jumpponen and Egerton-Warburton (2005). This may also explain the differences between EMF communities observed in both $B$. pendula and $P$. sylvestris growing in

Table 4 Means $( \pm$ SE) of taxonomic diversity and taxonomic distinctness of EMF communities associated with Betula pendula and Pinus sylvestris at contaminated (Bukowno, Miasteczko Śląskie, and Szopienice) and non-contaminated (Kórnik and Złoty Potok) sites; values within each column followed by the same letter are not significantly different according to Tukey's test at the $\alpha=0.05$ significance level

\begin{tabular}{lll}
\hline Site & $\begin{array}{l}\text { Taxonomic } \\
\text { diversity }\end{array}$ & $\begin{array}{l}\text { Taxonomic } \\
\text { distinctness }\end{array}$ \\
\hline $\begin{array}{l}\text { Betula pendula } \\
\text { Bukowno }\end{array}$ & $1.44(0.40) \mathrm{a}$ & $3.19(0.21) \mathrm{a}$ \\
Miasteczko & $1.39(0.16) \mathrm{a}$ & $2.42(0.06) \mathrm{a}$ \\
$\quad \begin{array}{l}\text { Sląskie } \\
\text { Szopienice }\end{array}$ & $1.44(0.52) \mathrm{a}$ & $2.47(0.07) \mathrm{a}$ \\
Kórnik & $2.24(0.92) \mathrm{a}$ & $3.16(0.93) \mathrm{a}$ \\
Złoty Potok & $0.31(0.26) \mathrm{a}$ & $1.99(0.76) \mathrm{a}$ \\
Pinus sylvestris & $1.56(0.50) \mathrm{a}$ & $3.14(0.30) \mathrm{a}$ \\
Bukowno & $1.31(0.19) \mathrm{a}$ & $2.43(0.33) \mathrm{a}$ \\
Miasteczko & & \\
$\quad$ Sląskie & $1.67(0.78) \mathrm{a}$ & $2.86(0.57) \mathrm{a}$ \\
Szopienice & $2.54(0.16) \mathrm{a}$ & $3.23(0.05) \mathrm{a}$ \\
Kórnik & $1.75(0.82) \mathrm{a}$ & $2.46(0.68) \mathrm{a}$ \\
Złoty Potok &
\end{tabular}

contaminated compared with control sites. In contrast to our results, Huang et al. (2014) reported a low similarity in the EMF communities of Pinus massoniana and Quercus fabri growing in Mn contaminated mine wasteland, which can be explained by host identity, one of the strongest factors shaping EMF communities (Ishida et al. 2007). More studies comparing EMF communities associated with different tree species on HM contaminated sites are needed to better understand the impact of soil factors as opposed to tree identity.

No significant differences were observed in the diversity of EMF communities between contaminated and non-contaminated soils in either $B$. pendula or $P$. sylvestris. Results of similar studies in sites contaminated with HMs are inconclusive. Some studies, like ours, indicate that there is no reduction in biodiversity of EMF communities. For example Hrynkiewicz et al. (2008) found that naturally established Salix caprea trees on former ore-bearing sites rich in $\mathrm{Zn}$ and $\mathrm{Cu}$ had EMF communities with a similar level of biodiversity as the fungal communities of $S$. caprea trees growing in soils not contaminated with HMs. Additionally, no significant changes in the diversity and richness of EMF communities associated with Pinus massoniana were observed at $\mathrm{Pb}-\mathrm{Zn}$ mine sites in central-south China (Huang et al. 2012). Other in situ studies revealed a significant reduction in the biodiversity of ectomycorrhizal fungi. For example, Staudenrausch et al. (2005) reported low diversity in EMF communities 


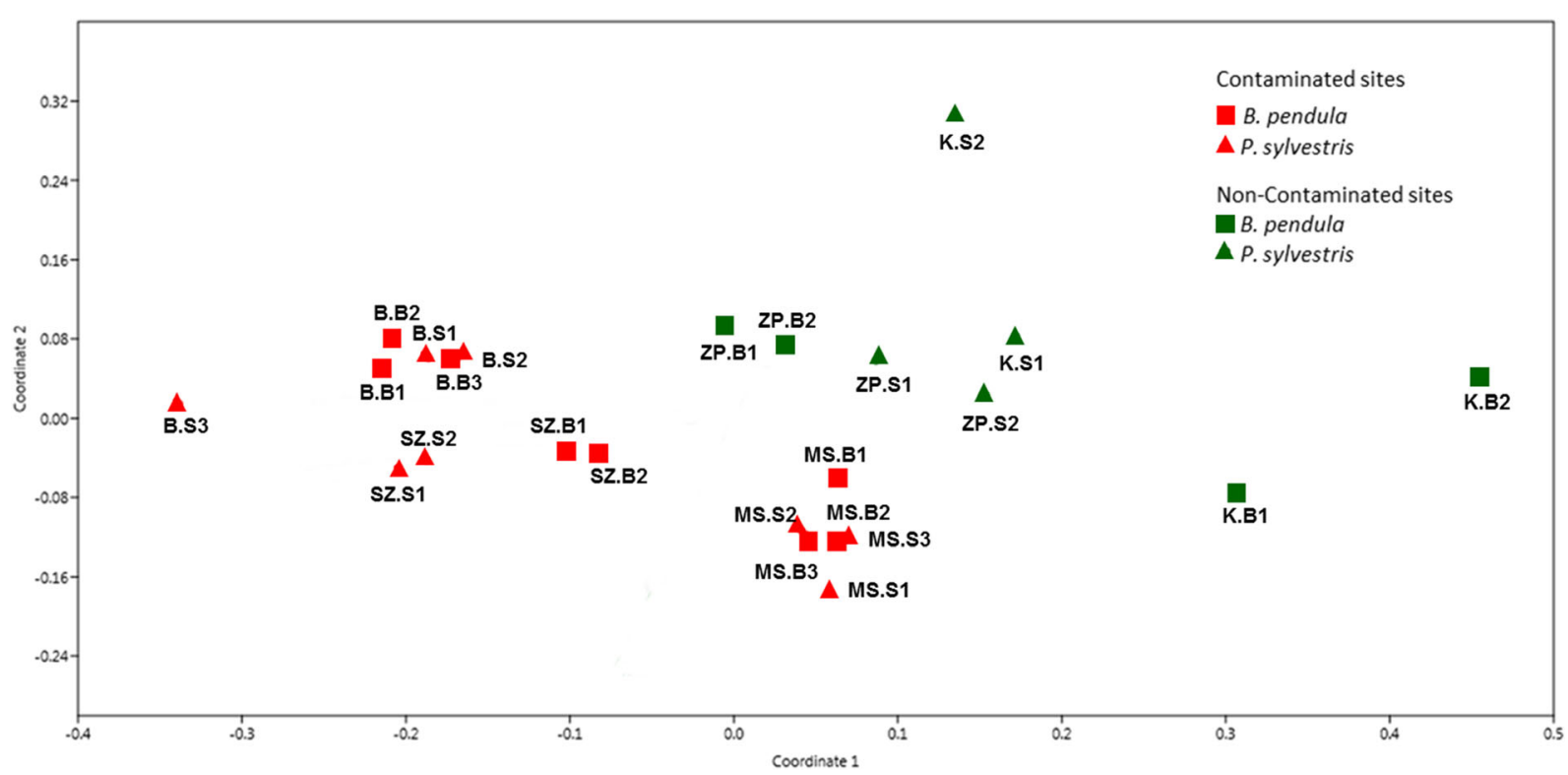

Fig. 2 Non-metric multidimensional scaling (NMDS) of the EMF communities associated with Betula pendula (Bp) and Pinus sylvestris (Ps) at contaminated (red marks) and non-

associated with Betula pendula growing at a site that was a former bare uranium heap. On the other hand,

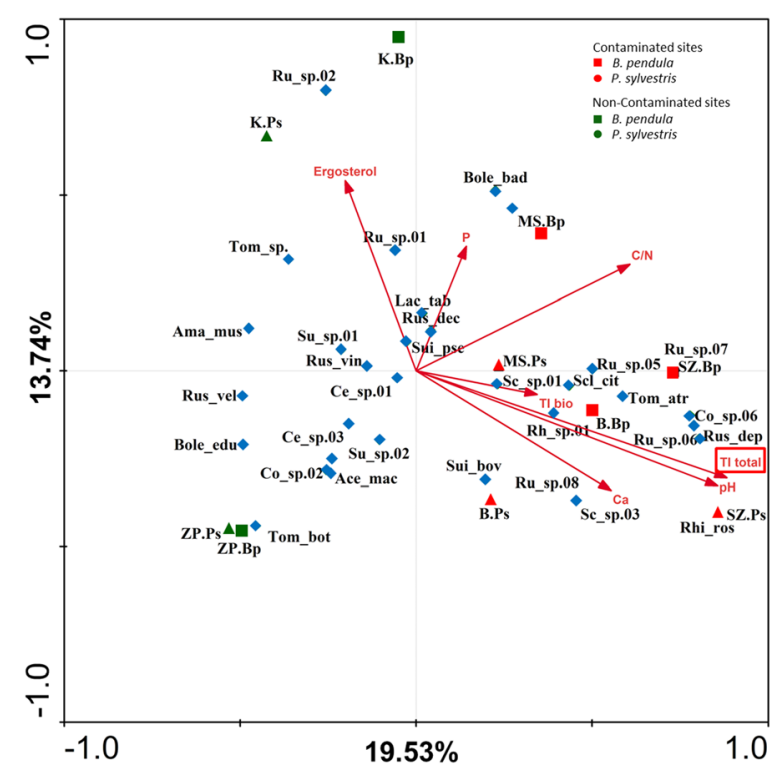

Fig. 3 CCA diagram of EMF species (green diamonds) associated with Betula pendula (Bp) and Pinus sylvestris (Ps) driven by environmental variables (red arrows). The red box indicates a statistically significant variable. EMF taxa whose relative abundance was $<5 \%$ were excluded from the analysis. The abbreviations of species names are expanded in Table 2. K - Kórnik; ZP Złoty Potok; B - Bukowno; MS - Miasteczko Śląskie; SZ Szopienice contaminated (green marks) sites. K - Kórnik; ZP - Złoty Potok; B - Bukowno; MS - Miasteczko Śląskie; SZ - Szopienice

Populus tremula growing around a former $\mathrm{Pb} / \mathrm{Zn}$ smelter was reported to have EMF communities that were highly diverse $\left(H^{\prime}=2\right)$ (Krpata et al. 2008). We, also postulate, similar to Huang et al. (2014), that some EMF species are well-adapted to high concentrations of HMs in soils and significantly impact the level of diversity of EMF communities in contaminated soils. However, as there is no consistency in the results obtained by different studies, there is an urgent need for further, more comprehensive empirical research.

The EMF communities associated with $B$. pendula and $P$. sylvestris growing in the contaminated sites studied were mainly composed of Russulaceae, Scleroderma spp., and Rhizopogon sp. (Table 2; Fig. 3). CCA analysis also indicated that the occurrence of some species belonging to the genus Russula is associated with high $\mathrm{TI}_{\text {Total }}$ and high soil $\mathrm{pH}$. Higher relative abundance of Russula species may reflect a higher HM resistance threshold of these fungi. Russula spp. have the ability to accumulate large amounts of HMs (Borovička and Řanda 2007; Busuioc and Elekes 2013). One of the mechanisms that enables Russula fungi to accumulate HMs is the synthesis of proteins similar to metallothioneins (low molecular mass intracellular peptides rich in cysteine that are capable of binding heavy metals) (Coyle et al. 2002) and the cysteine- and histidine-rich proteins (Leonhardt et al. 


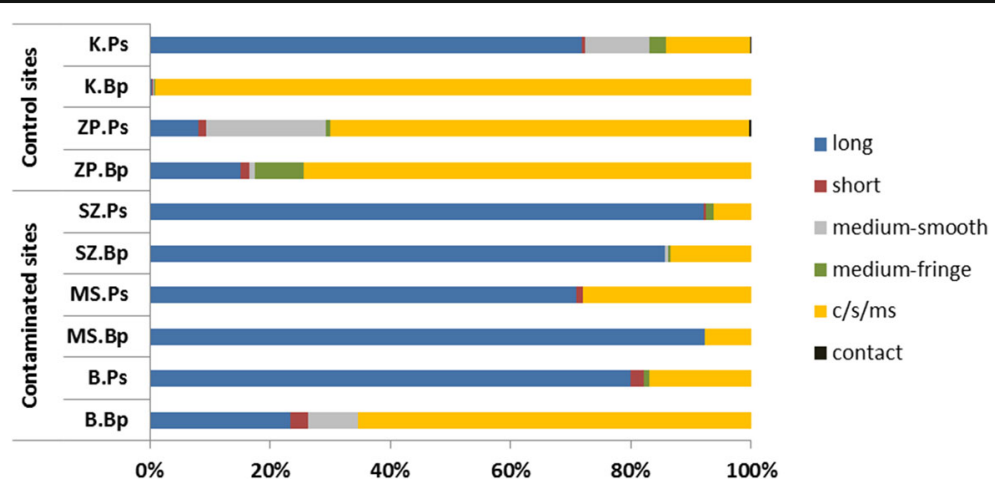

Fig. 4 Relative abundances (\%) of different exploration types of ectomycorrhizae collected in the study sites. K - Kórnik; ZP Złoty Potok; B - Bukowno; MS - Miasteczko Śląskie; SZ -

2014). Karpati et al. (2011), investigating ectomycorrhizae of Quercus rubra growing in urban soils, reported that Russula species are able to tolerate a wide range of environmental conditions, including high levels of HMs and salts.

Results of our study also indicated Scleroderma citrinum, Scleroderma sp.01, and Scleroderma sp.03 were associated with high levels of HMs (Fig. 3). Scleroderma species are ubiquitous in temperate forests and their fruiting bodies are often found in disturbed habitats (Gonzalez-Chavez et al. 2009; Krupa and

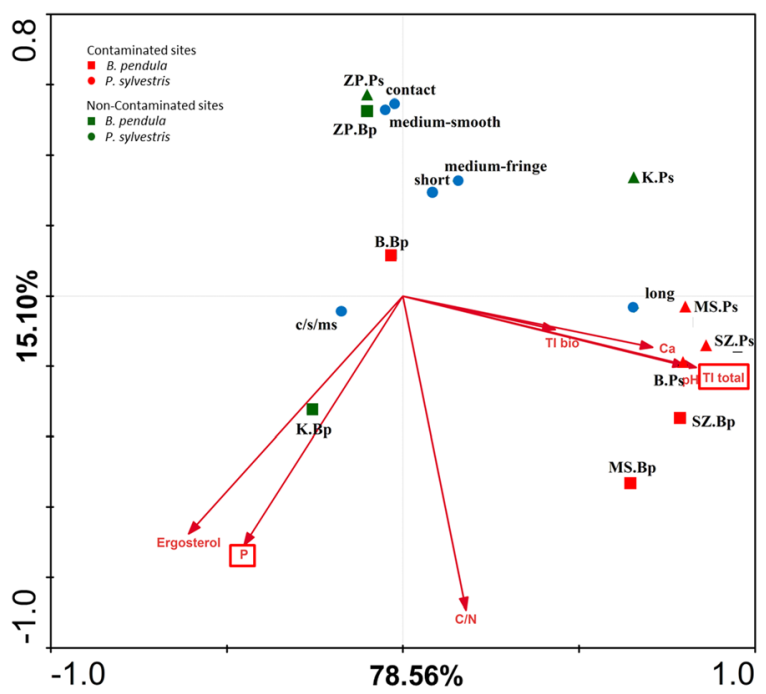

Fig. 5 CCA diagram of ECM exploration types (blue dots) driven by environmental variables (red arrows). The red boxes indicate statistically significant variables. K - Kórnik; ZP - Złoty Potok; B - Bukowno; MS - Miasteczko Ślaskie; SZ - Szopienice; Bp Betula pendula; $\mathrm{Ps}-$ Pinus sylvestris; $\mathrm{c} / \mathrm{s} / \mathrm{m}_{\mathrm{s}}-$ Russula, Lactarius, and Hygrophorus can be either contact (c), short (s) or mediumsmooth $\left(\mathrm{m}_{\mathrm{s}}\right)$ depending on the species
Szopienice; Bp - Betula pendula; Ps - Pinus sylvestris; $\mathrm{c} / \mathrm{s} / \mathrm{m}_{\mathrm{s}}{ }^{-}$ Russula, Lactarius, and Hygrophorus can be either contact (c), short (s),or medium-smooth $\left(\mathrm{m}_{\mathrm{s}}\right)$ depending on the species

Kozdrój 2007), including mine tailings containing high concentrations of HMs (Howe et al. 1997). We also observed ectomycorrhizae of Rhizopogon spp. abundant on contaminated sites in our study (Table 2). Turnau et al. (1996) demonstrated that $R$. roseolus has several mechanisms to tolerate HMs, such as binding HMs to polyphosphate granules and other amorphous or granular structures containing phosphorus, present in vacuole production of metal-binding pigments. Turnau et al. (1996) suggested that oxalate and carbonate crystals found on the surface of the $R$. roseolus mantle could also bind toxic metals, which was confirmed by Ahonen-Jonnarth et al. (2000).

The exploration types of ectomycorrhizae, based on the amount of emanating hyphae and the presence and differentiation of rhizomorphs, may mirror EMF ecological function (Agerer 2001). Results of our study indicated that the long-distance ectomycorrhizae dominated in HM-contaminated sites. Long-distance ectomycorrhizae, due to large amounts of emanating hyphae, may explore and take up nutrients as well as HMs from a vast soil volume. This ability may allow metal-tolerant EMF species to act like natural filters preventing toxic metals transfer to the host tree and helping them with nutrient supply (Colpaert et al. 2011). However, medium-fringe and contact exploration types were found dominating in other HMcontaminated sites (Rudawska et al. 2011; Hrynkiewicz et al. 2008, respectively). Rudawska et al. (2011) suggested that ectomycorrhizae of a medium-fringe exploration type were able to absorb vast amounts of toxic metals thus preventing their entrance into the host plant. On the other hand, Hrynkiewicz et al. (2008) postulated that ectomycorrhizae of contact 
exploration type, having small absorption surface area, were able to significantly reduce heavy-metals uptake.

The concentration of ergosterol was negatively correlated with the soil toxicity index, soil $\mathrm{pH}$ and $\mathrm{Ca}$ content (Fig. 3), which is in agreement with previous research (Bååth et al. 2005; Rousk et al. 2009). One of the reasons that soil fungal biomass decreased in soils containing high concentrations of HMs could be due to a deficiency of living fine roots, an essential factor in forming an ectomycorrhizal symbiotic relationship. Also, a lower biomass of saprotrophic fungi could result from lower amounts of good quality leaf litter and soil contamination. The negative correlation between soil fungal biomass and soil toxicity levels, $\mathrm{pH}$ and $\mathrm{Ca}$ content suggests that despite the tolerance of some EMF species to HM contaminated soils, high levels of HMs combined with specific soil conditions (high soil $\mathrm{pH}$ and $\mathrm{Ca}$ content in Bukowno and Szopienice), significantly reduces fungal biomass (Rousk et al. 2009). On the other hand, the presence of HMs in the soil may lead to changes in the community structure of soil microorganisms, causing an increase of saprophytic fungi over bacterial biomass, which is manifested by an increased concentration of ergosterol (Chander et al. 2001; Khan and Joergensen 2006).

\section{Conclusions}

Although species of tree is considered to be the major factor shaping the EMF community, phylogenetically distant tree species, such as B. pendula and P. sylvestris, growing in HM contaminated soils share similar EMF communities. This finding suggests that only welladapted EMF species with specific functional traits, like long-distance extrametrical mycelium, can survive toxic conditions and form ectomycorrhizal relationships with resident plant hosts. Among all of the examined soil factors studied, toxicity index $\left(\mathrm{TI}_{\mathrm{Total}}\right)$ was the most significant factor shaping the composition of EMF communities and ECM functional traits. Despite significant differences in the structure of the EMF community of trees growing in HM-contaminated sites compared to control sites, as well as differences in the amount of soil fungal biomass in the two different types of sites, no differences in overall diversity were observed. Results of the present study contribute to our understanding of the ecological response of ectomycorrhizal fungi and their hosts to heavy metal contamination, which is still a serious problem in historically industrialized areas and could benefit our ability to remediate these sites.

Acknowledgements We are grateful to Dr. Franco Magurno for his valuable and constructive comments on the original version of the manuscript and to Dr. Wojciech Baba for his statistical advice. Dr. Lynn Besenyei and Dr. Dale T. Karlson are acknowledged for their language correction.

Authors contribution $\mathrm{WB}, \mathrm{LKT}$, and RC designed the experiment; WB, LKT, and KB collected and $\mathrm{WB}, \mathrm{KB}, \mathrm{AT}$ and $\mathrm{IG}$ analyzed the samples; WB, AT, MD, and LKT analyzed the data; WB wrote the first draft of the manuscript, and all authors contributed substantially to revisions.

Open Access This article is licensed under a Creative Commons Attribution 4.0 International License, which permits use, sharing, adaptation, distribution and reproduction in any medium or format, as long as you give appropriate credit to the original author(s) and the source, provide a link to the Creative Commons licence, and indicate if changes were made. The images or other third party material in this article are included in the article's Creative Commons licence, unless indicated otherwise in a credit line to the material. If material is not included in the article's Creative Commons licence and your intended use is not permitted by statutory regulation or exceeds the permitted use, you will need to obtain permission directly from the copyright holder. To view a copy of this licence, visit http://creativecommons.org/licenses/by/4.0/.

\section{References}

Agerer R (2001) Exploration types of ectomycorrhizae. Mycorrhiza 11:107-114. https://doi.org/10.1007 /s005720100108

Ahonen-Jonnarth U, Van Hees PAW, Lundstrom U, Finlay RD (2000) Organic acids produced by mycorrhizal Pinus sylvestris exposed to elevated aluminium and heavy metal concentrations. New Phytol 146:557-567. https://doi. org/10.1046/j.1469-8137.2000.00653.x

Augustyniak M, Orzechowska H, Kędziorski A, Sawczyn T, Doleżych B (2014) DNA damage in grasshoppers' larvae comet assay in environmental approach. Chemosphere 96 : $180-187$. https://doi.org/10.1016/j. chemosphere.2013.10.033

Azarbad H, Niklińska M, Laskowski R, van Straalen NM, van Gestel CA, Zhou J, He Z, Wen C, Röling WF (2015) Microbial community composition and functions are resilient to metal pollution along two forest soil gradients. FEMS Microbiol Ecol 91:1-11. https://doi.org/10.1093 /femsec/fiu003

Bååth E, Diaz-Ravina M, Bakken LR (2005) Microbial biomass, community structure and metal tolerance of a naturally $\mathrm{Pb}$ enriched forest soil. Microb Ecol 50:496-505. https://doi. org/10.1007/s00248-005-0008-3

Bąba W, Błońska A, Kompała-Bąba A, Małkowski Ł, Ziemer B, Sierka E, Nowak T, Woźniak G, Besenyei L (2016) 
Arbuscular mycorrhizal fungi (AMF) root colonization dynamics of Molinia caerulea (L.) Moench. In grasslands and post-industrial sites. Ecol Eng 95:817-827. https://doi. org/10.1016/j.ecoleng.2016.07.013

Blaudez D, Botton B, Chalot M (2000) Cadmium uptake and subcellular compartmentation in the ectomycorrhizal fungus Paxillus involutus. Microbiology 146:1109-1117. https://doi.org/10.1099/00221287-146-5-1109

Borovička J, Řanda Z (2007) Distribution of iron, cobalt, zinc and selenium in macrofungi. Mycol Prog 6:249-259. https://doi. org/10.1007/s11557-007-0544-y

Busuioc G, Elekes CC (2013) Response of four Russula species under copper sulphate and lead acetate treatments. Not Bot Horti Agrobo 41:538-545. https://doi.org/10.15835 /nbha4129146

Chander K, Dyckmans J, Joergensen R, Meyer B, Raubuch M (2001) Different sources of heavy metals and their long-term effects on soil microbial properties. Biol Fertil Soils 34:241247. https://doi.org/10.1007/s003740100406

Cline ET, Ammirati JF, Edmonds RL (2005) Does proximity to mature trees influence ectomycorrhizal fungus communities of Douglas-fir seedlings? New Phytol 166:993-1009. https://doi.org/10.1111/j.1469-8137.2005.01387.x

Colpaert JV, Wevers JH, Krznaric E, Adriaensen K (2011) How metal-tolerant ecotypes of ectomycorrhizal fungi protect plants from heavy metal pollution. Ann For Sci 68:17-24. https://doi.org/10.1007/s13595-010-0003-9

Courbot M, Diez L, Ruotolo R, Chalot M, Leroy P (2004) Cadmium-responsive thiols in the ectomycorrhizal fungus Paxillus involutus. Appl Environ Microbiol 70:7413-7417. https://doi.org/10.1128/aem.70.12.7413-7417.2004

Coyle P, Philcox JC, Carey LC, Rofe AM (2002) Metallothionein: the multipurpose protein. Cell Mol Life Sci 59:627-647. https://doi.org/10.1007/s00018-002-8454-2

de Ridder-Duine AS, Smant W, van der Wal A, van Veen JA, de Boer W (2006) Evaluation of a simple, non-alkaline extraction protocol to quantify soil ergosterol. Pedobiologia 50: 293-300. https://doi.org/10.1016/j.pedobi.2006.03.004

Deng L, Zeng G, Fan C, Lu L, Chen X, Chen M, Wu H, He X, He Y (2015) Response of rhizosphere microbial community structure and diversity to heavy metal co-pollution in arable soil. Appl Microbiol Biotechnol 99:8259-8269. https://doi. org/10.1007/s00253-015-6662-6

Doğanlar Z, Atmaca M (2011) Influence of airborne pollution on $\mathrm{cd}, \mathrm{Zn}, \mathrm{Pb}, \mathrm{cu}$, and $\mathrm{Al}$ accumulation and physiological parameters of plant leaves in Antakya (Turkey). Water Air Soil Pollut 214:509-523. https://doi.org/10.1007/s11270-010$0442-9$

Edgar RC (2010) Search and clustering orders of magnitude faster than BLAST. Bioinformatics 26:2460-2461. https://doi. org/10.1093/bioinformatics/btq461

Edgar RC (2013) UPARSE: highly accurate OTU sequences from microbial amplicon reads. Nat Methods 10:996-998. https://doi.org/10.1038/nmeth.2604

Edgar R (2016) UCHIME2: improved chimera prediction for amplicon sequencing. BioRxiv 074252. https://doi. org $/ 10.1101 / 074252$

Glöckner FO, Yilmaz P, Quast C, Gerken J, Beccati A, Ciuprina A, Bruns G, Yarza P, Peplies J, Westram R, Ludwig W (2017) 25 years of serving the community with ribosomal
RNA gene reference databases and tools. J Biotechnol 261: 169-176. https://doi.org/10.1016/j.jbiotec.2017.06.1198

Gonçalves CS, Martins-Loução AM, Freitas H (2009) Evidence of adaptive tolerance to nickel in isolates of Cenococcum geophilum from serpentine soils. Mycorrhiza 19:221-230. https://doi.org/10.1007/s00572-008-0211-4

Gong P, Guan X, Witter E (2001) A rapid method to extract ergosterol from soil by physical disruption. Appl Soil Ecol 17:285-289. https://doi.org/10.1016/s0929-1393(01)00141$\mathrm{x}$

Gonzalez-Chavez MC, Carrillo-Gonzalez R, Gutierrez-Castorena MC (2009) Natural attenuation in a slag heap contaminated with cadmium: the role of plants and arbuscular mycorrhizal fungi. J Hazard Mater 161:1288-1298. https://doi. org/10.1016/j.jhazmat.2008.04.110

Górniak J (2010) Design of forest management plan for the Złoty Potok Forest District for the period from 1 January 2010 to 31 December 2019. Bureau for Forest Management and Geodesy, Cracow Division (in Polish)

Grodzińska K, Korzeniak U, Szarek-Łukaszewska G, Godzik B (2000) Colonization of zinc mine spoils in southern Poland preliminary studies on vegetation, seed rain and seed bank. Fragm Florist Geobot Pol 45:123-145

Hammer Ø, Harper DA, Ryan PD (2001) PAST: paleontological statistics software package for education and data analysis. Palaeontol Electron 4:1-9

Hannon, GJ (2010) FASTX-Toolkit http://hannonlab.cshl. edu/fastx toolkit/. Accessed 20 Jan 2020

Howe R, Evans RL, Ketteridge SW (1997) Copper-binding proteins in ectomycorrhizal fungi. New Phytol 135:123-131. https://doi.org/10.1046/j.1469-8137.1997.00622.x

Hrynkiewicz K, Haug I, Baum C (2008) Ectomycorrhizal community structure under willows at former ore mining sites. Eur J Soil Biol 44:37-44. https://doi.org/10.1016/j. ejsobi.2007.10.004

Huang J, Nara K, Lian C, Zong K, Peng K, Xue S, Shen Z (2012) Ectomycorrhizal fungal communities associated with Masson pine (Pinus massoniana lamb) in $\mathrm{Pb}-\mathrm{Zn}$ mine sites of central South China. Mycorrhiza 22:589-602. https://doi. org/10.1007/s00572-012-0436-0

Huang J, Nara K, Zong K, Wang J, Xue S, Peng K, Shen Z, Lian C (2014) Ectomycorrhizal fungal communities associated with Masson pine (Pinus massoniana) and white oak (Quercus fabri) in a manganese mining region in Hunan Province, China. Fungal Ecol 9:1-10. https://doi.org/10.1016/j. funeco.2014.01.001

Ishida TA, Nara K, Hogetsu T (2007) Host effects on ectomycorrhizal fungal communities: insight from eight host species in mixed conifer-broadleaf forests. New Phytol 174: 430-440. https://doi.org/10.1111/j.1469-8137.2007.02016.x

Jackson RB, Canadell J, Ehleringer JR, Mooney HA, Sala OE, Schulze ED (1996) A global analysis of root distributions for terrestrial biomes. Oecologia 108:389-411. https://doi. org/10.1007/bf00333714

Jaśniska-M'Bodj A (2015) Design of forest management plan for the Złoty Potok Forest District for the period from 1 January 2016 to 31 December 2025. Bureau for Forest Management and Geodesy, Cracow Division (in Polish)

Jourand P, Ducousso M, Reid R, Majorel C, Richert C, Riss J, Lebrun M, Epron D (2010) Nickel-tolerant ectomycorrhizal Pisolithus albus ultramafic ecotype isolated from nickel 
mines in New Caledonia strongly enhance growth of the host plant Eucalyptus globulus at toxic nickel concentrations. Tree Physiol 30:1311-1319. https://doi.org/10.1093 /treephys/tpq070

Jumpponen A, Egerton-Warburton L (2005) Mycorrhizal Fungi in successional environments: a community assembly model incorporating host plant, environmental, and biotic filters. In: Dighton J, White JF, Oudemans P (eds) The fungal community: its organization and role in the ecosystem, 3rd edn. Taylor \& Francis Group, CRC Press, Boca Raton, pp 139-168.

Karpati AS, Handel SN, Dighton J, Horton TR (2011) Quercus rubra-associated ectomycorrhizal fungal communities of disturbed urban sites and mature forests. Mycorrhiza 21:537547. https://doi.org/10.1007/s00572-011-0362-6

Khan KS, Joergensen RG (2006) Decomposition of heavy metal contaminated nettles (Urtica dioica L.) in soils subjected to heavy metal pollution by river sediments. Chemosphere 65 : $981-987$. https://doi org/10.1016/j. chemosphere.2006.03.038

Kõljalg U, Nilsson RH, Abarenkov K, Tedersoo L, Taylor AF, Bahram M, Bates ST, Bruns TD, Bengtsson-Palme J, Callaghan TM, Douglas B, Drenkhan T, Eberhardt U, Dueñas M, Grebenc T, Griffith GW, Hartmann M, Kirk PM, Kohout P, Larsson E, Lindahl BD, Lücking R, Martín MP, Matheny PB, Nguyen NH, Niskanen T, Oja J, Peay KG, Peintner U, Peterson M, Põldmaa K, Saag L, Saar I, Schüßler A, Scott JA, Senés C, Smith ME, Suija A, Taylor DL, Telleria MT, Weiss M, Larsson KH (2013) Towards a unified paradigm for sequence-based identification of fungi. Mol Ecol 22:5271-5277. https://doi.org/10.1111/mec.12481

Krpata D, Peintner U, Langer I, Fitz WJ, Schweiger P (2008) Ectomycorrhizal communities associated with Populus tremula growing on a heavy metal contaminated site. Mycol Res 112:1069-1079. https://doi.org/10.1016/j. mycres.2008.02.004

Krupa P, Kozdrój J (2007) Ectomycorrhizal fungi and associated bacteria provide protection against heavy metals in inoculated pine (Pinus sylvestris L.) seedlings. Water Air Soil Pollut 182:83-90. https://doi.org/10.1007/s11270-006-9323-7

Leonhardt T, Sácký J, Šimek P, Šantrůček J, Kotrba P (2014) Metallothionein-like peptides involved in sequestration of $\mathrm{Zn}$ in the $\mathrm{Zn}$-accumulating ectomycorrhizal fungus Russula atropurpurea. Metallomics 6:1693-1701. https://doi. org/10.1039/c4mt00141a

Levitt J (1980) The responses of plants to environmental stress, vol. 2. Water, radiation, salt and other stresses. Academic Press, New York

Leyval C, Turnau K, Haselwandter K (1997) Effect of heavy metal pollution on mycorrhizal colonization and function: physiological, ecological and applied aspects. Mycorrhiza 7:139153. https://doi.org/10.1007/s005720050174

López-García Á, Gil-Martínez M, Navarro-Fernández CM, Kjøller R, Azcón-Aguilar C, Domínguez MT, Marañón T (2018) Functional diversity of ectomycorrhizal fungal communities is reduced by trace element contamination. Soil Biol Biochem 121:202-211. https://doi.org/10.1016/j. soilbio.2018.03.021

Łukasik I (2006) Degradation of beech ancient forests Luzulo pilose - Fagetum under diverse anthropopression in
Wyżyna Śląsko-Krakowska. Wyd Uniw Śląskiego, Katowice (in Polish)

Misiorny R (2009) Design of forest management plan for the Babki Forest District for the period from 1 January to 31 December 2018. Bureau for Forest Management and Geodesy, Poznań Division (in Polish)

Olsson PA, Chalot M, Bååth E, Finlay RD, Söderström B (1996) Ectomycorrhizal mycelia reduce bacterial activity in a sandy soil. FEMS Microbiol Ecol 21:77-86. https://doi. org/10.1111/j.1574-6941.1996.tb00335.x

Olsson PA, Larsson L, Bago B, Wallander H, Van Aarle IM (2003) Ergosterol and fatty acids for biomass estimation of mycorrhizal fungi. New Phytol 159:1-10. https://doi. org/10.1046/j.1469-8137.2003.00810.x

Pennanen T, Frostegard ASA, Fritze H, Bååth E (1996) Phospholipid fatty acid composition and heavy metal tolerance of soil microbial communities along two heavy metalpolluted gradients in coniferous forests. Appl Environ Microbiol 62:420-428. https://doi.org/10.1128 /aem.62.2.420-428.1996

Picon-Cochard C, Coll L, Balandier P (2006) The role of belowground competition during early stages of secondary succession: the case of 3-year-old scots pine (Pinus sylvestris L) seedlings in an abandoned grassland. Oecologia 148:373383. https://doi.org/10.1007/s00442-006-0379-2

Piekut A, Gut K, Ćwieląg-Drabek M, Domagalska J, Marchwińska-Wyrwał E (2019) The relationship between children's non-nutrient exposure to cadmium, lead and zinc and the location of recreational areas-based on the upper Silesia region case (Poland). Chemosphere 223:544-550. https://doi.org/10.1016/j.chemosphere.2019.02.085

Pongrac P, Zhao FJ, Razinger J, Zrimec A, Regvar M (2009) Physiological responces to $\mathrm{cd}$ and $\mathrm{Zn}$ in two $\mathrm{cd} / \mathrm{Zn}$ hyperaccumulating Thlaspi species. Environ Exp Bot 66: 479-486. https://doi.org/10.1016/j.envexpbot.2009.03.010

Prach K, Pyšek P (2001) Using spontaneous succession for restoration of human-disturbed habitats: experience from Central Europe. Ecol Eng 17:55-62. https://doi.org/10.1016/s09258574(00)00132-4

Ragnarsdottir KV, Hawkins DP (2006) Bioavailable copper and manganese in soils from Iceland and their relationship with scrapie occurrence in sheep. J Geochem Explor 88:228-234. https://doi.org/10.1016/j.gexplo.2005.08.046

Ramesh G, Podila GK, Gay G, Marmeisse R, Reddy MS (2009) Different patterns of regulation for the copper and cadmium metallothioneins of the ectomycorrhizal fungus Hebeloma cylindrosporum. Appl Environ Microbiol 75:2266-2274. https://doi.org/10.1128/aem.02142-08

Regvar M, Likar M, Piltaver A, Kugonič N, Smith JE (2010) Fungal community structure under goat willows (Salix caprea L) growing at metal polluted site: the potential of screening in a model phytostabilisation study. Plant Soil 330: 345-356. https://doi.org/10.1007/s11104-009-0207-7

Robert V, Vu D, Amor AB, van de Wiele N, Brouwer C, Jabas B, Szoke S, Dridi A, Triki M, Ben Daoud S, Chouchen O, Vaas L, de Cock A, Stalpers JA, Stalpers D, Verkley GJ, Groenewald M, Dos Santos FB, Stegehuis G, Li W, Wu L, Zhang R, Ma J, Zhou M, Gorjón SP, Eurwilaichitr L, Ingsriswang S, Hansen K, Schoch C, Robbertse B, Irinyi L, Meyer W, Cardinali G, Hawksworth DL, Taylor JW, Crous PW (2013) MycoBank gearing up for new horizons. IMA 
Fungus 4:371-379. https://doi.org/10.5598 /imafungus.2013.04.02.16

Rosling A, Landeweert R, Lindahl BD, Larsson KH, Kuyper TW, Taylor AFS, Finlay RD (2003) Vertical distribution of ectomycorrhizal fungal taxa in a podzol soil profile. New Phytol 159:775-783. https://doi.org/10.1046/j.14698137.2003.00829.x

Rousk J, Brookes PC, Bååth E (2009) Contrasting soil pH effects on fungal and bacterial growth suggest functional redundancy in carbon mineralization. Appl. Environ Microbiol 75: 1589-1596. https://doi.org/10.1128/AEM.02775-08

Rubino FM (2015) Toxicity of glutathione-binding metals: a review of targets and mechanisms. Toxics 3:20-62. https://doi.org/10.3390/toxics3010020

Rudawska M, Leski T, Stasińska M (2011) Species and functional diversity of ectomycorrhizal fungal communities on scots pine (Pinus sylvestris L.) trees on three different sites. Ann For Sci 68:5-15. https://doi.org/10.1007/s13595-010-0002-x

Sastre J, Sahuquill A, Vidal M, Rauret G (2002) Determination of $\mathrm{cd}, \mathrm{cu}, \mathrm{Pb}$ and $\mathrm{Zn}$ in environmental samples: microwaveassisted total digestion versus aqua regia and nitric acid extraction. Anal Chim Acta 462:59-72. https://doi. org/10.1016/s0003-2670(02)00307-0

Schützendübel A, Polle A (2002) Plant responses to abiotic stresses: heavy metal-induced oxidative stress and protection by mycorrhization. J Exp Bot 53:1351-1365. https://doi. org/10.1093/jexbot/53.372.1351

Seregin IV, Ivanov VB (2001) Physiological aspects of cadmium and lead toxic effects on higher plants. Russ J Plant Physiol 48:523-544

Staudenrausch S, Kaldorf M, Renker C, Luis P, Buscot F (2005) Diversity of the ectomycorrhiza community at a uranium mining heap. Biol Fertil Soils 41:439-446. https://doi. org/10.1007/s00374-005-0849-4

Stefanowicz AM, Niklińska M, Laskowski R (2008) Metals affect soil bacterial and fungal functional diversity differently. Environ Toxicol Chem 27:591-598. https://doi.org/10.1897 /07-288.1

Szeremeta M (2010) Design of forest management plan for the Katowice Forest district as per 1 January 2010. Bureau for Forest Management and Geodesy, Cracow Division (in Polish)

ter Braak CJF, Šmilauer P (2002) CANOCO reference manual and User's guide to CANOCO for windows: software for canonical community ordination (version 4.5). Microcomputer power, Ithaca, New York

Trocha LK, Kałucka I, Stasińska M, Nowak W, Dabert M, Leski T, Rudawska M, Oleksyn J (2012) Ectomycorrhizal fungal communities of native and non-native Pinus and Quercus species in a common garden of 35-year-old trees. Mycorrhiza 22:121-134. https://doi.org/10.1007/s00572-011-0387-x

Turnau K, Kottke I, Dexheimer J (1996) Toxic element filtering in Rhizopogon roseolus/Pinus sylvestris mycorrhizas collected from calamine dumps. Mycol Res 100:16-22. https://doi. org/10.1016/s0953-7562(96)80094-3

Turnau K, Mleczko P, Blaudez D, Chalot M, Botton B (2002) Heavy metal binding properties of Pinus sylvestris mycorrhizas from industrial wastes. Acta Soc Bot Pol 71:253-261. https://doi.org/10.5586/asbp.2002.030

Warwick RM, Clarke KR (1998) Taxonomic distinctness and environmental assessment. J Appl Ecol 35:532-543. https://doi.org/10.1046/j.1365-2664.1998.3540532.x

Welp G (1999) Inhibitory effects of the total and water-soluble concentrations of nine different metals on the dehydrogenase activity of a loess soil. Biol Fertil Soils 30:132-139. https://doi.org/10.1007/s003740050599

White TJ, Bruns TD, Lee SB, Taylor JW (1990) Amplification and direct sequencing of fungal ribosomal RNA genes for phylogenetics. In: Innis MA, Gelfand DH, Sninsky JJ, White TJ (eds) PCR Protocols: A guide to methods and applications. Academic Press, San Diego, pp 315-322.

Wierzbicki, J. (2012) Design of forest management plan for the Katowice Forest district for the period from 1 January 2013 to 31 December 2023. Bureau for Forest Management and Geodesy, Brzeg Division (in Polish)

Wilkinson DM, Dickinson NM (1995) Metal resistance in trees: the role of mycorrhizae. Oikos 72:298-300. https://doi. org/10.2307/3546233

Wójcik M, Sugier P, Siebielec G (2014) Metal accumulation strategies in plants spontaneously inhabiting $\mathrm{Zn}-\mathrm{Pb}$ waste deposits. Sci Total Environ 487:313-322. https://doi. org/10.1016/j.scitotenv.2014.04.024

Publisher's note Springer Nature remains neutral with regard to jurisdictional claims in published maps and institutional affiliations. 